\title{
The Barremian heteromorph ammonite Dissimilites from northern Italy: Taxonomy and implications
}

Alexander Lukeneder and Susanne Lukeneder

Acta Palaeontologica Polonica 59 (3), 2014: 663-680 doi: http://dx.doi.org/10.4202/app.2012.0014

A new acrioceratid ammonite, Dissimilites intermedius sp. nov., from the Barremian (Lower Cretaceous) of the Puez area (Dolomites, northern Italy) is described. Dissimilites intermedius sp. nov. is an intermediate form between $D$. dissimilis and $D$. trinodosum. The new species combines the ribbing style of $D$. dissimilis (bifurcating with intercalating single ribs) with the tuberculation style of $D$. trinodosum (trituberculation on entire shell). The shallow-helical spire, entirely comprising single ribs intercalated by trituberculated main ribs, is similar to the one of the assumed ancestor Acrioceras, whereas the increasing curvation of the younger forms resembles similar patterns observed in the descendant Toxoceratoides. These characters support the hypothesis of a direct evolutionary lineage from Acrioceras via Dissimilites to Toxoceratoides. D. intermedius sp. nov. ranges from the upper Lower Barremian (Moutoniceras moutonianum Zone) to the lower Upper Barremian (Toxancyloceras vandenheckii Zone). The new species allows to better understand the evolution of the genus Dissimilites. The genus appears within the Nicklesia pulchella Zone represented by $D$. duboise, which most likely evolved into $D$. dissimilis . In the Kotetishvilia compressissima Zone, two morphological forms developed: smaller forms very similar to Acrioceras and forms with very long shaft and juvenile spire like in D. intermedius sp. nov. The latter most likely gave rise to $D$. subalternatus and D. trinodosum in the M. moutonianum Zone, forms which were probably ancestral to the genus Toxoceratoides.

Key words: Ammonoidea, Acrioceratidae, Dissimilites, Barremian, Cretaceous, Alps, Italy.

Alexander Lukeneder [alexander.lukeneder@nhm-wien.ac.at], Geological-Palaeontological Department, Natural History Museum, Burgring 7, 1010 Vienna, Austria; Susanne Lukeneder [susanne.lukeneder@nhm-wien.ac.at], Geological-Palaeontological Department, Natural History Museum, Burgring 7, 1010 Vienna and Department of Palaeontology, University of Vienna, Althanstrasse 14, 1090 Wienna, Austria. 
This is an open-access article distributed under the terms of the Creative Commons

Attribution License (for details please see creativecommons.org), which permits unrestricted use, distribution, and reproduction in any medium, provided the original author and source are credited.

FoF 